\title{
HUMANITIES
}

ESSAY

\section{Triumph of the spirit}

Previously published at www.cmaj.ca

One of us (RF) comes from a large family in Hungary, dating back many generations. After World War II, the daughter of a surviving aunt returned to Hungary to explore family roots. The search turned up a small diary, published in 1873, by an ancestor physician, Dr. Sigismund Finaly (18081876). ${ }^{1}$ The following excerpt from that diary is an extraordinary example of a number of current topics in medical education and medical ethics, including patient autonomy, cultural sensitivity and mind-body interaction.

I $\mathrm{t}$ was a cold winter in 1838 and I was a medical student in attendance in the lecture hall of the University of Pest in Hungary. The noted surgeon Professor Stahly was to demonstrate a routine case and the auditorium gradually filled with incoming students, as the professor took his place at the podium. Suddenly his assistant broke in, quite agitated, and announced the arrival of a desperately ill patient from a distant village. "Can you accept him?"

"Yes, of course," said Professor Stahly. "In such cases we do not stand on ceremony or formalities."

The door swung open and three individuals entered the hall. The scene was charged. The central figure, was a 30-year-old gaunt, poverty stricken man who looked as if he had just been taken out of a torture chamber. His left arm, or what was left of it, hung in a sling. To his left stood his wife, forlorn, dressed in rags, and to the right the \& local peasant who had driven him on a full night's journey through the winter night all the way from the outlying village of Hatvan to the medical center.

Three days earlier the man's sleeve had been sucked into the machinery of the local flour mill and his arm had

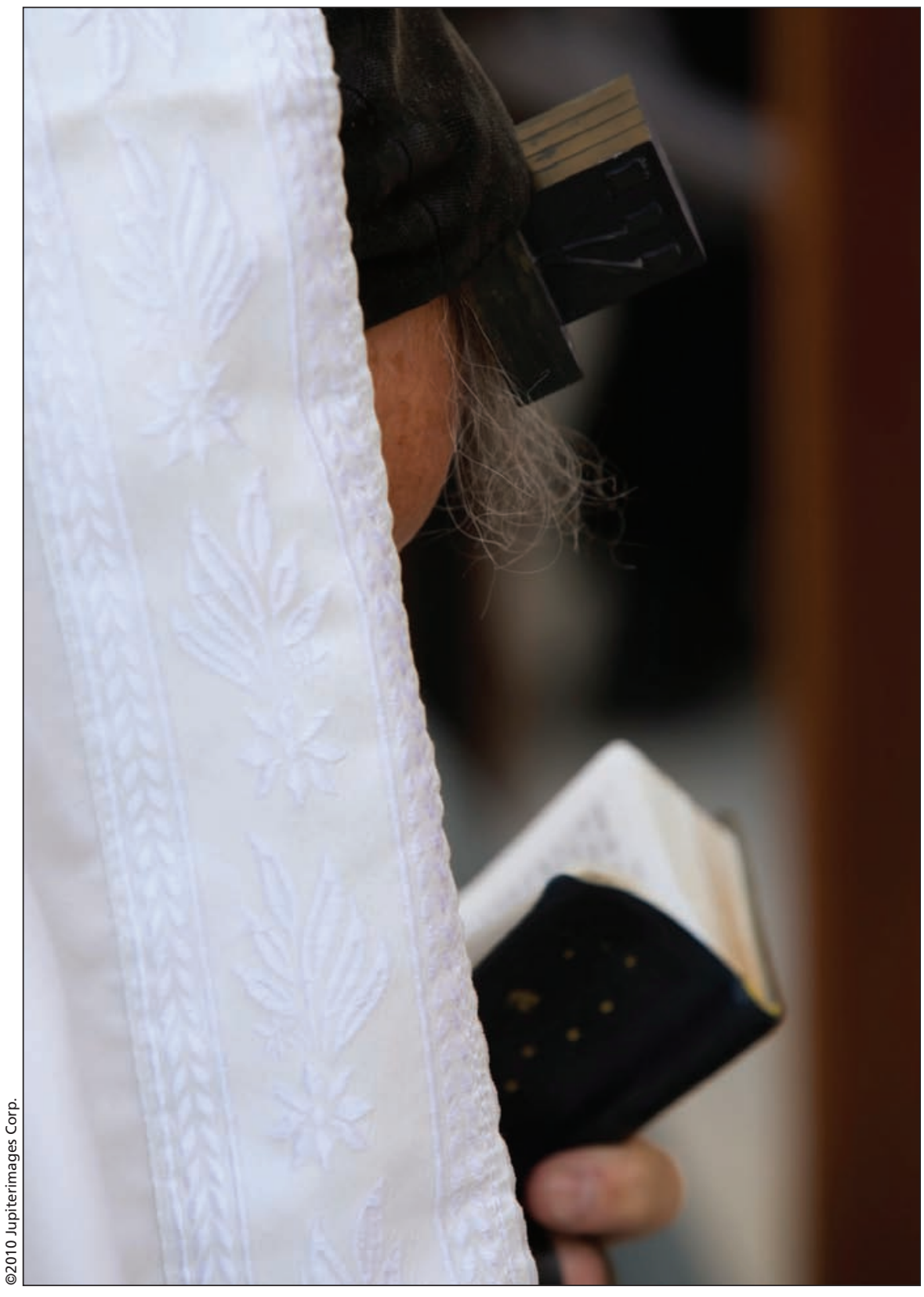

been crushed up to the elbow. Although the man had been treated by the local physician his condition had worsened progressively and his physician referred him to the university hospital.

The bandages were removed, and we all could see the bruised and crushed arm. Total silence reigned and all eyes moved from the desperate patient to Professor Stahly. The latter stood motionless and gazed at what was left of the man's limb.

At last the professor broke his silence and addressed the medical stu- 
dents, "Well gentlemen, we shall have to do an above the elbow amputation. In the patient's present condition this may be the only way to save his life. We will operate immediately." He then turned to the patient, explaining to him in a few words the importance and urgency of the operation. The patient, in apparent disbelief, asked the surgeon to repeat his verdict, which Professor Stahly did. A dialogue ensued.

The patient: "My distinguished professor, I cannot consent to the amputation of my arm."

Professor Stahly: "You are obviously afraid that you may die and that you will suffer agonizing pain. But do not fear - you will survive the surgery and you will recover. But without surgical intervention we cannot save your life; and as I see you have a wife and perhaps also some children."

Patient: "Yes, sir, indeed I am married and have three children, but my life is in the hands of God. I am not afraid to die. I am not afraid of pain. But despite that I cannot and must not permit this amputation!"

It became clear to us students that no amount of persuasion would change this patient's mind.

Professor Stahly turned to the audience, "In my long career I have had to convince many such patients who were afraid of surgery, but I have never encountered such stubbornness as in this man." Turning to the patient he asked, "Pray tell me please what is the reason that you are so opposed to amputation of your arm?"

The patient explained, "Sir, this is the arm on which I put on tefilin."

Total silence came over the auditorium. No one in the audience, made up almost entirely of non-Jews, nor Professor Stahly had the slightest idea what the man was talking about. I stood up and asked permission to speak, which was granted. I explained that tefilin (phylacteries) were made of small leather boxes with holy text inside and leather straps wrapped around the left arm. This was done by adult male devout Jews every morning in their prayers as a pious expression of their devotion and commitment to their Creator.

Much to my consternation a loud burst of laughter emerged from no small number of the audience. Professor Stahly leaped to his feet turned towards the scoffers and reprimanded them in no uncertain terms: "Who are these meanspirited individuals who would mock a patient because of his deeply held religious beliefs? Leave the auditorium and I do not want your participation ever in my lectures."

To those remaining in the lecture hall he said: "We have before us a wounded person who can be saved only by an amputation. But since the patient refuses consent we cannot treat him. What shall we do? Send him out in the snowy winter cold? No! Let him stay here with us in the hospital. True, he will undoubtedly die. But you have to learn how to deal with this experience as well."

The patient was transferred to a quiet room, the wounds treated and his wife was permitted to stay with him. I was instructed by the professor to contact the Jewish community and to see that he and his wife were provided with kosher food.

I was deeply impressed by the case and for some time visited the patient daily. Not surprisingly his medical situation seemed hopeless; high fever, inflammation, weakness seemed to portend his impending demise ...

In the course of the following months, I was assigned to another institution and lost contact with the patient, who passed out of my consciousness.

Over the next few years I was busy with my developing private practice.

One cool spring day in 1843 while walking down the street I saw a familiar face alongside a farmer's wagon. I approached the man and asked him,
"Did I ever treat you? Do you recognize me?"

"Of course I do. You used to visit me daily in the hospital and provided me with my personal needs!"

"And this is your arm?" I asked, incredulously, observing the functional, albeit deformed, limb.

"Yes! This is my tefilin arm."

That afternoon I visited my colleague Dr. Ratzu who worked at the university clinic. He provided me with the followup history of the patient. He had been desperately ill for many weeks and all had expected his early death. But slowly, under treatment with quinine, the inflammation subsided, some of the bony fragments were excised, and by the end of the academic year the patient had recovered and returned to his village. But not before Professor Stahly presented him again to the class at the final lecture of the academic year. In the last sentence of his presentation Professor Stahly stated, "Faith can move mountains. While to us, doctors, logic and rationality are essential tools, but by their very nature they arouse doubts. Faith alone can move mountains. In this case the deep belief in God brought about the healing of our patient. Despite all the medical odds stacked against him he stands before you today with all of his limbs intact."

The lesson was clear.

\section{Shimon M. Glick MD \\ Robert Finaly MD}

Faculty of Health Sciences

Ben-Gurion University of the Negev

Beer-Sheva, Israel

Acknowledgements: The authors thank Mrs. Miriam Lava of the Finaly family for making the diary available to us and to Dr. Mark Clarfield and Dr. Alan Jotkowitz for their helpful comments.

\section{REFERENCE}

1. Finaly S. Aus dem Tagebuch eines Arztes. Heft Pest 1873. Druck von Khor und Wein. 